\title{
Assessment of Heavy Metals in Water of Selected Places of Nellore coast of Andhra Pradesh through Atomic Absorption Spectroscopy
}

\author{
Vardi Venkateswarlu ${ }^{1 *}$, Chenji Venkatrayulu ${ }^{2}$ \\ ${ }^{1}$ Research Scholar, Department of Marine Biology, Vikrama Simhapuri University, Nellore-524320, Andhra Pradesh, \\ India \\ ${ }^{2}$ Assistant Professor, Department of Marine Biology, Vikrama Simhapuri University, Nellore-524320, Andhra Pradesh, \\ India
}

*Address for Correspondence: Mr. Vardi Venkateswarlu, Research Scholar, Department of Marine Biology, Vikrama Simhapuri University, Nellore- 524320, Andhra Pradesh, India

E-mail: venkat9160@gmail.com

Received: 13 Apr 2019/ Revised: 21 Jul 2019/ Accepted: 16 Aug 2019

\begin{abstract}
Background: The rapid industrialization of the coastal areas has resulted in marine pollution in different regions of the Southeast coast of India. The quality of coastal and marine water affected by the toxic pollutants released from the industrial activities and urbanization has been assessed in terms of pollution. The present study area also referred that the industrial activity is more responsible for marine pollution, causing toxic effects by heavy metals.

Methods: For the present study water samples collected from Nelaturu, Krishnapatnam coastal villages of Nellore and samples brought to the laboratory for heavy metals analysis by Atomic Absorption Spectroscopy (AAS) standard methods followed by American Public Health Association (APHA).

Results: During the present study the heavy metals Arsenic, Lead, Cadmium, Mercury, Iron, Manganese, Copper, Zinc concentrations were observed, shown in Table 1 and discussed the levels when compared with water quality standards given by the Indian Standards (IS: 10500) and WHO guidelines.

Conclusion: The present study sites are one of the famous places for marine fishing area having near thermal power plants and port activities. In our study, there were eight heavy metals were determined, which were observed in 2 sampling sites i.e. Nelaturu, Krishnapatnam in Nellore district. The study had been concluded with the future impact of heavy metals in the marine environment and to the aquatic life as well as to human life at Nellore coast.
\end{abstract}

Key-words: Atomic Absorption Spectroscopy (AAS), Coastal water pollution, Heavy metals, Mineralogical contamination, Nellore coast

\section{INTRODUCTION}

Coastal water pollution is one of the major environmental problems in the worldwide. The coastal water pollution is due to the mineralogical contamination and dumping of the untreated industrial and municipal wastes directly into the sea coasts through canals. Heavy metals are generally water-soluble, no degradable, vigorous oxidizing agents and are strongly

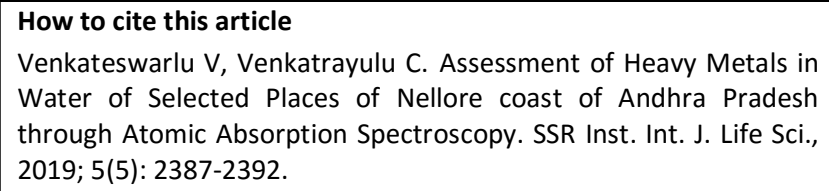

Venkateswarlu V, Venkatrayulu C. Assessment of Heavy Metals in Water of Selected Places of Nellore coast of Andhra Pradesh through Atomic Absorption Spectroscopy. SSR Inst. Int. J. Life Sci., 2019; 5(5): 2387-2392.

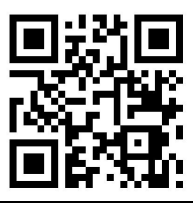

Access this article online https://iijls.com/ bonded with many biochemicals inhibiting their functions. The rapid industrialization in coastal regions resulted in environmental pollution and higher quantities of heavy metals are being added into the natural estuarine and coastal environments. The heavy metal contamination in the coastal water has connections directly to the biota and indirectly to human life. They will also cause irregularity in blood; badly affect the major functioning organs like kidneys and liver. Heavy metals including both essential and nonessential elements have a particular significance in ecotoxicology since they are highly persistent and all have the potential to be toxic to the living organisms ${ }^{[1]}$.

Heavy metals are considered the foremost anthropogenic contaminants in coastal and marine environments worldwide ${ }^{[2]}$. 
They pose a serious threat to human health, natural ecosystems and living organisms because of their toxicity, persistence and bioaccumulation characteristics ${ }^{[3]}$. Numerous substantial heavy metals are known to be toxic or carcinogenic to humans ${ }^{[4]}$ and also play a significant role as sensitive indicators for monitoring contaminants in aquatic systems ${ }^{[5]}$. Several studies have demonstrated that marine sediments are highly polluted by heavy metals ${ }^{[6]}$. Therefore; the evaluation of metal distribution in surface sediment is useful to assess pollution in the marine environment along the east coast of India. Industrial activities, economic development, and urbanization of all over the globe have risen very quickly in recent years and substantial quantities of contaminants are introduced into rivers, estuarine areas and coastal regions ${ }^{[7]}$. The water which provides habitats for many aquatic organisms was polluted with various forms of hazardous and toxic substances, including heavy metals ${ }^{[8]}$. As a result, they are considered to be important carriers as well as the heavy metals in the aquatic cycle is important to know the distribution and concentration of heavy metals in the study area. In several studies, many authors investigated the distribution of heavy metals and the pollution status using environmental assessment indices.

The present work would be of assistance to the relevant researchers in ensuring a heavy metals status of the neighboring coastal water bodies in Nellore, Andhra Pradesh and would function as a foundation for further work for the present study area.

This work carried out to elucidate the coastal management by providing primary data sets for decisionmaking policyholders. Also beside, the baseline information will form a flat form for the stakeholders to monitor the coastal pollution by inexpensive biomarkers and also manage and conserve the study area from further pollution hazards. Further, the pollution levels for the study area can be constantly monitored to safeguard the fishing community and biodiversity.

\section{MATERIALS AND METHODS}

The present study conducted during the month of April 2019 by the Department of Marine Biology, Vikrama Simhapuri University, Nellore, Andhra Pradesh, India.

Study Area- The Nellore district has a $169 \mathrm{~km}$ of the coastal line with habitation of fishermen community along the east coast of India. The Nellore coastal region is suitable for the brackishwater aquaculture farming, recently gradually increased some industrial activities. The present sampling sites of Nelaturu and Krishnapatnam coastal areas have thermal power industries and also shipping activities from this coastal region (Fig. 1).

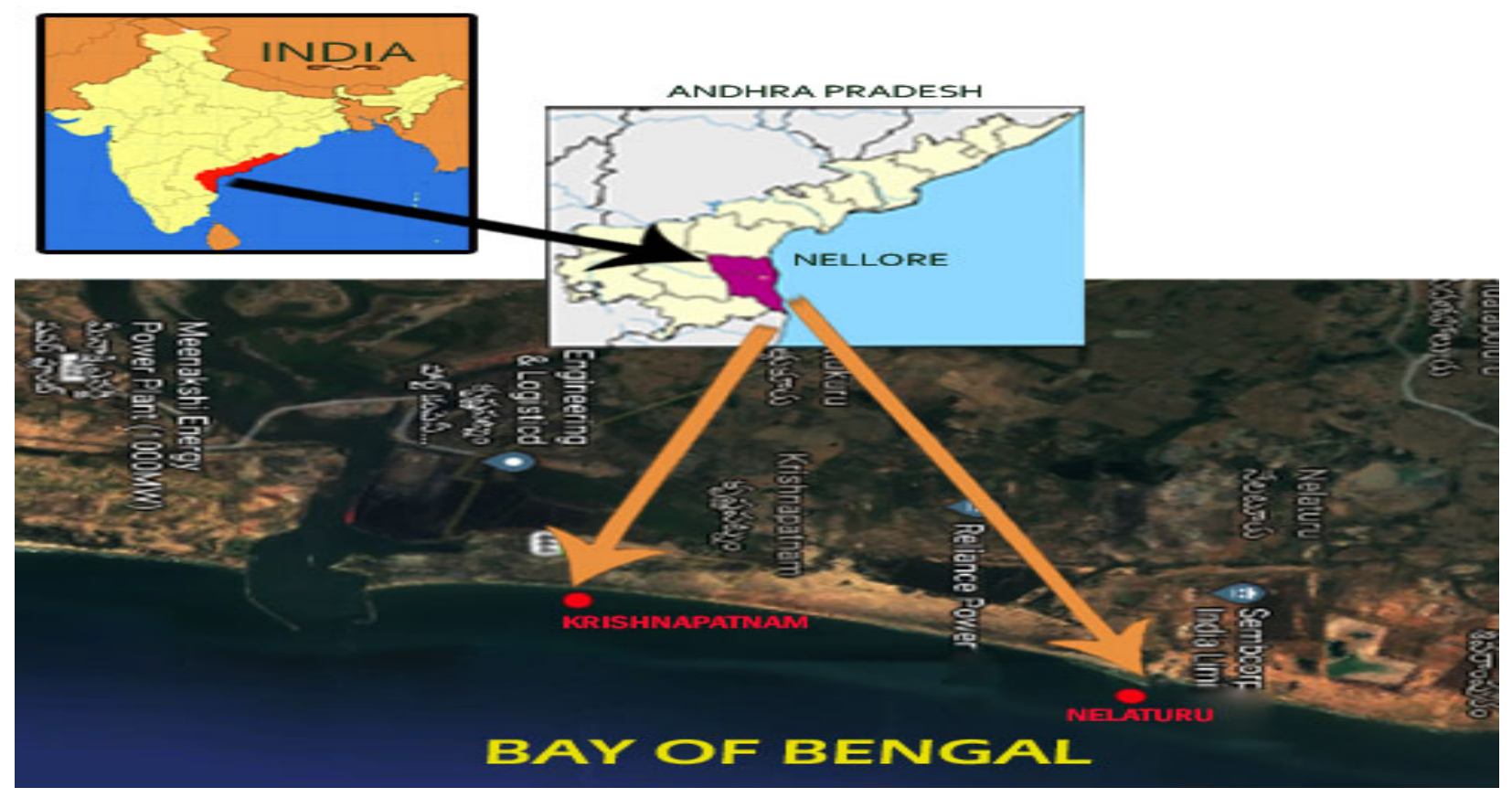

Fig. 1: Map showing the study areas of Nelaturu and Krishnapatnam coastal regions of Nellore coast of Andhra Pradesh in India 
Sample collection- The coastal saltwater samples were collected by following the quality sample assortment protocol and tips given in Indian Standards strategies IS 3025 part-1 and APHA twenty-second edition. The special precautions were taken throughout the sampling of water within the elite places of study areas. Before the gathering of the samples, the sample containers square measure soaked night long in a pair of aqua fortis and washed with double $\mathrm{H}_{2} \mathrm{O}$ and dried during a clean space. At every sampling location, water samples were collected in 2 pre-cleaned containers for duplicate mensuration. The bottles were rinsed thrice with the coastal saltwater sample of the actual location. Total 0.5 $\mathrm{mL}$ of above pure grade aqua fortis was added into the collected samples to avoid the contamination and also to stop the loss of metals from the sample. All the collected samples were preserved at $4^{\circ} \mathrm{C}$ by employing a thermocoal box with ice packs at the sample assortment site.

Sample preparation for analysis- The digestion procedure for water samples was carried out by transferring a measured volume $(50 \mathrm{~mL})$ of well-mixed acid preserved water sample to a conical flask then $5 \mathrm{~mL}$ of concentrated nitric acid (Conc. $\mathrm{HNO}_{3}$ ) was added into the flask. The water sample and Nitric acid mixture were boiled and evaporated on a hot plate to the lowest volume of up to 10 to $20 \mathrm{ml}$. Continued the heating and adding conc. Nitric acid $\left(\mathrm{HNO}_{3}\right)$ to the sample digestion was complete to show by a light color clear solution in the sample digestion conical flask. After that conical flask was washed down with distilled water and filtered. Then the filtrate was transferred into $10 \mathrm{~mL}$ volumetric flask with two $5 \mathrm{ml}$ of water, adding these rinsing to the volumetric flask and cooled and diluted to the mark and mixed thoroughly followed by Brooks et al. ${ }^{[9]}$. A portion of the sample solution was taken for the required metal determinations flowed by APHA ${ }^{[10]}$.
Heavy metals analysis by Atomic Absorption Spectroscopy- AAS is most widely using an analytical technique for the determination of trace and heavy metals up to parts per billion levels. AAS is a very useful technique to determine trace levels of multi-elements in single aspiration. AA-6800 AAS coupled with GFA-EX7 graphite furnace atomizer and ASC-6100 auto sampler from Shimadzu (Koyoto, Japan) was used for heavy metal analysis. A high-density graphite tube was used for atomization. Normal single hollow cathode lamps were used for irradiation followed by APHA ${ }^{[10]}$.

\section{RESULTS}

The ranges of the heavy metals viz., Arsenic (As), Lead $(\mathrm{Pb})$, Cadmium (Cd), Mercury (Hg), Iron (Fe), Manganese $(\mathrm{Mn})$, Copper $(\mathrm{Cu})$ and Zinc $(\mathrm{Zn})$ presented in the coastal water of Nelaturu, Krishnapatnam regions of Nellore coast in summer April 2019 during the study period observed the industrial activities in thermal power station and shipping activities are more. The concentration of $\mathrm{Pb}$ maximum range $4.67 \pm 0.12$ was observed at Nelaturu coast, and $3.03 \pm 1.13$ found at Krishnapatnam. Cd maximum range $3.03 \pm 1.13$ was observed at Krishnapatnam than Nelaturu 2.66 \pm 0.09 . The levels of As observed nearly in Krishnapatnam $1.20 \pm 0.001$ and in Nelaturu $1.16 \pm 0.02$ was observed. However the concentration of $\mathrm{Cu}$ was $0.09 \pm 0.001$ observed more than the permissible range at Krishnapatnam coast and $\mathrm{As}, \mathrm{Pb}, \mathrm{Cd}, \mathrm{Cu}$ were more than permissible levels and $\mathrm{Fe}$ and $\mathrm{Zn}$ were observed within the ranges of IS 10500 and WHO water safety guidelines. $\mathrm{Hg}, \mathrm{Mn}, \mathrm{Cu}, \mathrm{Zn}$ were not observed at Nelaturu coast whereas, $\mathrm{Hg}$ and $\mathrm{Mn}$ were not observed at Krishnapatnam coast. The concentrations of heavy metals obtained from AAS analysis is presented in Table 1.

Table 1: Heavy metals in the coastal water of (Nelaturu, Krishnapatnam) Nellore (mg/lt) Mean \pm SD $(n=6)$ in Andhra Pradesh, comparison with WHO and IS: 10500 standards

\begin{tabular}{cccccc}
\hline S.No. & $\begin{array}{c}\text { Name of the } \\
\text { Metal }\end{array}$ & $\begin{array}{c}\text { Nelaturu COAST } \\
\text { (Mean } \pm \text { SD) }\end{array}$ & $\begin{array}{c}\text { Krishnapatnam Coast } \\
\text { (Mean } \pm \text { SD) }\end{array}$ & $\begin{array}{c}\text { IS } \mathbf{1 0 5 0 0} \\
\text { Standards }\end{array}$ & $\begin{array}{c}\text { W.H.O } \\
\text { Standards }\end{array}$ \\
\hline $\mathbf{1}$ & Arsenic $(\mathrm{As})$ & $1.16 \pm 0.02$ & $1.20 \pm 0.001$ & 0.01 & 0.01 \\
$\mathbf{2}$ & Lead $(\mathrm{Pb})$ & $4.67 \pm 0.12$ & $3.64 \pm 0.02$ & 0.01 & 0.01 \\
$\mathbf{3}$ & Cadmium $(\mathrm{Cd})$ & $2.66 \pm 0.09$ & $3.03 \pm 1.13$ & 0.003 & 0.003
\end{tabular}




\begin{tabular}{rccccc}
$\mathbf{4}$ & Mercury (Hg) & N.D & N.D & 0.001 & 0.001 \\
$\mathbf{5}$ & Iron (Fe) & $0.04 \pm 0.004$ & $0.01 \pm 0.0 .001$ & 0.3 & 0.2 \\
$\mathbf{6}$ & Manganese (Mn) & N.D & N.D & 0.1 & 0.5 \\
$\mathbf{7}$ & Copper (Cu) & N.D & $0.09 \pm 0.001$ & 0.05 & 2.0 \\
$\mathbf{8}$ & Zinc (Zn) & N.D & $0.01 \pm 0.002$ & 5.0 & 3.0 \\
\hline
\end{tabular}

N.D $=$ Not Detected

\section{DISCUSSION}

The ranges of the heavy metals were present in the coastal water of Nelaturu, Krishnapatnam coastal regions of Nellore coast in the present study obtained from AAS analysis as discussed below. Although there was no clear definition of what a heavy metal density is in most cases taken to be the defining factor. Heavy metals are thus generally defined as those having a specific density of more than $5 \mathrm{~g} / \mathrm{cm}^{3}$. Heavy metals are among the most common environmental pollutants, and their occurrence in water and biota indicate the presence of natural or anthropogenic sources. Although adverse health effects of heavy metals have been known for a long time, discharge of heavy metals continues and is even increasing in some areas are particularly in less developed countries. The main threats to human health from heavy metals are associated with exposure to lead, cadmium and mercury. Their accumulation and distribution in soil, sediments and aquatic environment are increasing at an alarming rate thereby affecting marine life ${ }^{[11-13]}$.

A number of elements are normally present in relatively low to high concentrations, usually more than a few $\mathrm{mg} / \mathrm{L}$, in conventional irrigation water and are called trace elements. Heavy metals are a special group of trace elements which have been shown to create definite health hazards when taken up by plants. The observed experimental value was very much higher than the permissible limit of iron, which was $0.3 \mathrm{mg} / \mathrm{L}$. The presence of a high concentration of Fe may increase the hazard of pathogenic organisms; since most of these organisms need Fe for their growth ${ }^{[14]}$.

Arsenic (As) concentrations were observed $1.16 \mathrm{mg} / \mathrm{L}$ in Nelaturu beach, $1.20 \mathrm{mg} / \mathrm{L}$ in Krishnapatnam coast. The maximum concentrations were observed in both study areas. The permissible limit for Arsenic as per IS: 10500 is $0.01 \mathrm{mg} / \mathrm{L}$ and maximum guideline value as per the WHO is $0.01 \mathrm{mg} / \mathrm{L}$. However, the observed concentration levels of Arsenic in the study area were observed as excess than acceptable limits given by the IS: 10500 and WHO guidelines. Long-time exposure to arsenic in drinking water can cause cancer in the skin, lungs, bladder, and kidney. It can also cause other skin changes such as thickening and pigmentation ${ }^{[15]}$.

Lead $(\mathrm{Pb})$ concentrations were observed $4.67 \mathrm{mg} / \mathrm{L}$ in Nelaturu, $3.64 \mathrm{mg} / \mathrm{L}$ in Krishnapatnam coast. The maximum concentrations were observed in both study areas. The permissible limit for Lead is as per IS: 10500 is $0.01 \mathrm{mg} / \mathrm{L}$. Lead is a highly toxic metal substance, exposure to which can produce a wide range of adverse health effects in both adults and children. Every year, industries producing about 2.5 million tons of lead throughout the world that used for making batteries. In adults, lead can increase blood pressure and cause infertility problems, nerve disorders, muscle and joint pain, irritability and memory or concentration problems come ${ }^{[16,18]}$.

Cadmium ( $\mathrm{Cd}$ ) concentrations were observed $2.66 \mathrm{mg} / \mathrm{L}$ in Nelaturu, $3.03 \mathrm{mg} / \mathrm{L}$ in Krishnapatnam coast the maximum concentrations were observed in both study areas. The permissible limit for Cadmium is as per IS: 10500 is $0.003 \mathrm{mg} / \mathrm{L}$. cadmium is widely distributed in the earth's crust and is principally used in many industries and in agriculture, according to USPH standards. Higher values of $\mathrm{Cd}$ in wastewater effluent samples suggest the high level of pollution due to dyes paints and pigments manufacturing industries [14]. Cadmium targets the liver, placenta, kidneys, lungs, brain, and bones. Consumption of food or drinking water with very high cadmium levels severely irritates the stomach, leading to vomiting and diarrhea and sometimes causes death ${ }^{[17]}$.

Mercury $(\mathrm{Hg})$ concentrations were observed $<1.0 \mathrm{mg} / \mathrm{L}$ below Detection Level (BDL) in Nelaturu and Krishnapatnam coast. The maximum acceptable limit for Mercury as per IS: 10500 is $0.001 \mathrm{mg} / \mathrm{L}$ permissible value 
and values are within the permissible limits given by IS: 10500 and WHO guidelines. There are three forms of mercury and among these the most toxic one is the organic form, viz., methyl mercury. Methyl mercury is a microbiologically transformed form of inorganic mercury when it reaches aquatic environments, water bodies or in soils. Inorganic and organic mercury is toxic to the human body in different ways, affecting different organs in different ways it may primarily expose to mercury via food, where fish is the major source of methyl mercury exposure by biomagnification. Mercury has no necessary function in any living organism and is considered as a non-essential metal, and is among the most toxic elements to man and many higher animals ${ }^{[19]}$.

Iron concentrations were observed $0.0487 \mathrm{mg} / \mathrm{L}$ in Nelaturu, $0.0107 \mathrm{mg} / \mathrm{L}$ in Krishnapatnam coast. The maximum acceptable limit for iron as per IS: 10500 is 0.3 $\mathrm{mg} / \mathrm{L}$ and no guideline value was given by the WHO for Iron content. However, the observed concentration levels of Iron found within the permissible given by the IS: $10500-\mathrm{CPCB}^{[20]}$.

Manganese $(\mathrm{Mn})$ concentrations were observed $<1.0$ $\mathrm{mg} / \mathrm{L}$ BDL in Nelaturu and Krishnapatnam coast. The maximum acceptable limit for Manganese as per IS: 10500 is $0.1 \mathrm{mg} / \mathrm{L}$ and permissible value $0.3 \mathrm{mg} / \mathrm{L}$ and provisional guideline value as per the $\mathrm{WHO}$ is $0.4 \mathrm{mg} / \mathrm{L}$. The observed manganese values were within the permissible limits given by IS: 10500 and WHO guidelines $\mathrm{CPCB}^{[20]}$.

Copper (Cu) concentrations were observed $<1.0 \mathrm{mg} / \mathrm{L}$ BDL in Nelaturu, $0.096 \mathrm{mg} / \mathrm{L}$ in Krishnapatnam coast. It is within the permissible limits at Nelaturu given by IS: 10500 and WHO guidelines. Copper is one of the essential metals to life despite being as inherently toxic as non-essential heavy metal exemplified by lead and mercury. Plants and animals rapidly accumulate it. It is toxic at minute low concentration in water and is known to cause brain damage in mammals. The natural inputs of copper to the marine aquatic environment are from erosion of mineralized rocks or maybe from the industries. Anthropogenic inputs of copper are from industries and paints. It also forms complexes with organic molecules. Mollusks have a tremendous capacity to accumulate copper from contaminated water-CPCB [20].

$\mathrm{Zn}$ concentrations were observed $<1.0 \mathrm{mg} / \mathrm{L} \mathrm{BDL}$ in Nelaturu, $0.01 \mathrm{mg} / \mathrm{L}$ in Krishnapatnam coast. It is within the permissible limits at Nelaturu given by IS: 10500 and WHO guidelines. Zinc is an essential nutrient for the human body and has importance for health also it acts as a catalytic or structural component in many enzymes that are involved in energy metabolism also. Symptoms of zinc toxicity are slow reflexes, tremors, paralyzation of extremities, anemia, metabolic disorder, teratogenicity effects and increased mortality in humans-CPCB ${ }^{[20]}$.

In the present seawater study, the heavy metals of mercury, manganese and copper concentrations in the seawater have been observed in $B D L<1.0 \mathrm{mg} / \mathrm{L}$. Increased toxic heavy metal concentrations in the water lead to the Bioaccumulation factor in the aquatic food chain and it showed the transfer of metals especially arsenic, lead, cadmium, mercury are warning signal for fish consumption by humans towards food safety ${ }^{[20,21]}$.

\section{CONCLUSIONS}

The environmental parameters of water can be affected by the toxicity of the metal either by influencing the physiology of organisms or by altering the chemical form of the metal in water. The increased ambient heavy metal concentration will result in accumulation in the tissues of commercially important edible finfish, shell fish. It is an inherent danger of higher bioaccumulation of toxins in the edible species that may result in severe health hazards to the consumers especially human. It was evident that the present study on heavy metals in the water of the Nellore coast suggested adopting effective heavy metal removal technologies to control the toxic metal contamination in coastal water.

Further bioaccumulation study to be needed for better understanding the metal toxicity in the coastal and marine environment.

\section{ACKNOWLEDGMENTS}

Authors are thankful to the Vimta Laboratories Pvt. Ltd. Nellore, for Atomic Absorption Spectroscopy analysis.

\section{CONTRIBUTION OF AUTHORS}

Research concept- Dr. Ch. Venkatrayulu

Research design- Dr. Ch. Venkatrayulu

Supervision- Dr. Ch. Venkatrayulu

Materials- Mr. V. Venkateswarlu

Data collection- Mr. V. Venkateswarlu

Data analysis and Interpretation- Mr. V. Venkateswarlu

Literature search- Mr. V. Venkateswarlu

Writing article- Mr. V. Venkateswarlu

Critical review- Mr. V. Venkateswarlu 
Article editing- Dr. Ch. Venkatrayulu

Final approval- Dr. Ch. Venkatrayulu

\section{REFERENCES}

[1] Storelli MM, Storelli A, D'Addabbo R, Marano C, Bruno $R$, et al. Trace elements in loggerhead turtles (Caretta caretta) from the eastern Mediterranean Sea: overview and evaluation. Environ. Pollut., 2005; 135: 163-70.

[2] Naser HA. Assessment and management of heavy metal pollution in the marine environment of the Arabian Gulf: review. Marine Pollut. Bull., 2013; 72: 06-13.

[3] Deforest D, Brix K, Adams W. Assessing metal bioaccumulation in aquatic environments: The inverse relationship between bioaccumulation factors, trophic transfer factors and exposure concentration. Aquat. Toxicol., 2007; 84: 236-46.

[4] Fu F, Wang Q. Removal of heavy metal ions from waste waters. A review. J. Environ. Manag., 2011; 92: 407-18.

[5] Ozkan EY, Buyu KB. Geochemical and statistical approach for assessing heavy metal accumulation in the southern Black Sea sediments. Ekoloji., 2012; 21(83): 11-24.

[6] Pande N, Nayak GN. Understanding distribution and abundance of metals with space and time in estuarine mud flat sedimentary environment. Environ. Earth Sci., 2013; 70: 2561-75.

[7] Ravichandran R, Manickam S. Heavy metal distribution in the coastal sediment of Chennai Coast. IIOAB J., 2012; 3(2): 12-18.

[8] Baran A, Tarnawski M. Assessment of heavy metals mobility and toxicity in contaminated sediments by sequential extraction and a battery of bio assays. Eco. Toxicol., 2015; 24(6): 1279-93.

[9] Matoso E, Kubota LT, Cadore S. Talanta. Use of silica gel chemically modified with zirconium phosphate for pre-concentration and determination of lead and copper by flame atomic absorption spectrometry. Talanta, 2003; 60(6): 1105-11.
[10]APHA. Standard methods for examination of water and waste water. $22^{\text {nd }}$ Edition. American Public Health Association, Washington DC., 2012.

[11]Koukal B, Dominik J, Vignati D, Arpagaus P, et al. Assessment of water quality and toxicity of polluted rivers Fez and Sebou in the region of Fez (Morocco). Benaabidate, Environ. Pollut., 2004; 31(1): 163-72.

[12]Mohiuddin KM, Zakir HM, Otomo K, Sharmin S, et al. Geochemical distribution of trace metal pollutants in water and sediments of downstream of an urban river. Int. J. Environ. Sci. Tech., 2010; 7(1): 17-28.

[13]Okafor EC, Opuene K. Preliminary assessment of trace metals and polycyclic aromatic hydrocarbons in the sediments. Int. J. Environ. Sci. Tech., 2007 4(2): 233-40.

[14]Tiwana NS, Jerath N, Singh G, Ravleen M. (Eds.) Heavy metal pollution in Punjab rivers, in Newsletter Environmental Information System (ENVIS), 3(1): pp.03-07, Punjab State Council for Science and Technology, India.

[15]Ferner DJ. Toxicity and Heavy Metals. eMed. J., 2001; 2(5): 01.

[16]Gopinathan KM, Amma SR. Bioaccumulation of toxic heavy metals in the edible soft tissues of green mussel (Perna viridis L.) of Mahe region. Project report submitted to the Department of Science, Technology and Environment (DSTE), Government of Pondicherry, 2008, 01-32.

[17]Sindhu PS. Environ. Chem., 2002 pp.75-243, $1^{\text {st }}$ ed., New Age International (P) Ltd., New Delhi.

[18]Salem HM, Eweida A, Azza F. Heavy metals in drinking water and their environmental impact on human health, Center for Environmental Hazards Mitigation, 2000; pp. 542-56.

[19]Jarup L. Hazards of heavy metal contamination. British Med. Bull., 2003; 68: 167-82.

[20]CPCB. Impact of Coal Mine Waste water Discharge on surroundings with reference to heavy metals. Central Pollution Control Board Bhopal, 2011.

[21] Utete B, Nhiwatiwa T, Barson M, Mabika N. Heavy metal bioaccumulation in edible fish species from an industrially polluted river and human health risk assessment. Int. J. Water Sci., 2013; 2(4): 01-08. 